\title{
Green Apparel Buying Behaviour: Opportunities in Indian Market
}

\author{
Arpita Khar* \\ Indian Institute of Management Rohtak, India \\ *Corresponding author: Arpita Khar, Indian Institute of Management Rohtak, Haryana, India
}

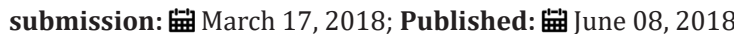

\begin{abstract}
This review examines the factors affecting organic clothing purchase behaviour. Review of literature reveals that past green buying behaviour, peer influence, green apparel knowledge were important for consumers. However, several studies posit that awareness about environmental problems does not necessarily translate into green buying. Organic clothing purchase behaviour can be influenced by several factors like green attitudes, self-identity, past experience with green products and social groups.
\end{abstract}

Keywords: Green knowledge; Green peer influence; Green apparel buying; Indian youth

\section{Introduction}

Most studies in green buying behaviour discuss the importance of environment friendly attitudes, awareness about environmental problems, and psychological factors in predicting consumers' behaviour for green products [1-3]. Several researchers posit that knowledge about environmental problems does not necessarily translate into green product purchase [4,5]. In emerging economies, like India, growing environmental problems have led government to promote green awareness and practices [6-9]. In similar vein, the current study analyzes the organic clothing trends in Indian market. Indian apparel industry is growing at a fast pace. Press releases suggest that it is valued at $\$ 40$ billion and estimated to grow to a $\$ 124$ billion market by 2020 [10]. Changing lifestyle, increase in the number of women in workforce, availability of global apparel brands in the country, rising income, awareness about global fashion trends has led to growth of the apparel industry $[11,12]$. Recent years have witnessed an interest in organic apparel and it contributes around five percent of the total apparel market [13]. Many national and international apparel manufacturers like Wills Lifestyle, Van Heusen, Benetton, S Kumar's Nationwide and Arrow have introduced organic apparel lines by using recycled fibers to produce organic clothing [14]. Apparel brand like levis has launched eco denims for both men and women while Van Heusen and Arrow have launched organic clothing brands [14,15]. Government and apparel manufacturers are taking initiatives to develop technologies that reduce carbon emissions [16]. The factors identified from the study can help in formulating research plan to conduct a systematic quantitative research to understand green apparel buying behaviour. Indian green apparel market is growing and understanding the purchase behaviour, product choice related factors, and psychological factors would provide information to apparel companies.

\section{Green buying behaviour}

In previous studies researcher have discussed the importance of several factors like attitudes, values, past buying behaviour, lifestyle, personality, peer influence, and product attributes on green buying behaviour [17-26].

Social conformance, group identity, and personal values have been reported to be important predictors to environmentally friendly behaviour. Kalafatis et al. [27] applied the Theory of Planned Behaviour (TPB) to compare environmental attitudes of Greek and British consumers. They state that beliefs and social norms influenced intention to purchase green products. Kim \& Chung [28] found that environmental and appearance consciousness and past experiences with other organic products influenced attitudes towards green products. Similarly, Cheah \& Phau [29] reported that environmental norms/values influenced purchase of environmentally friendly products. Environmental knowledge and past experience with green products was important in predicting environment friendly behaviour [30-33]. Mostafa [23] stated that though people professed awareness about environment related problems, it did not translate into willingness to purchase green products.

\section{Green apparel purchase behaviour}

Several studies have discussed the importance of organic clothing as a means of supporting green values. It helped in showing one's commitment towards environment. The decision to 
purchase organic clothing depends on several factors like concern for environmental problems, social norms, green lifestyle, and trust in green products. Research in different countries posits growing awareness about green products. Personality, lifestyle, and attitude towards environment were important in predicting intention to purchase green products. Gam [34] found that consumers' fashion orientation, shopping styles, environmental concern, and ecofriendly behaviour predicted their preference for organic clothing. In another research, Gam et al. [35] studied role of consumer characteristics on willingness to pay for kids' organic clothing. They found that environmental concern, green buying and recycling behaviour influenced mothers' intention to buy organic clothing for kids. They were not willing to pay premium prices for purchasing organic clothing. Lin [36] characterized environmental shopping attitudes under four dimensions: involvement in an environmental organization or other environmental protection activities, consumption of organic food, interest in the fabric content label prior to the purchase of a garment, and past purchase of organic apparels. Environmentally conscious consumers were willing to pay higher price for organic clothing [37].

In a research conducted on Indian consumers' organic clothing purchase, Khare \& Varshneya [38] studied the influence of past green buying, green apparel knowledge and peer influence on organic clothing purchase behaviour of Indian youth. The findings provided interesting insight and differ from earlier studies on green buying that argue the importance of social influence and green norms [25,27-29,39]. Indian youth's past experience with green products and brands enabled them to appreciate the relevance of organic clothing. Since peer influence had no impact on organic clothing purchase behaviour of youth, it could imply that organic clothing helped in expressing one's commitment towards environment and therefore views of others was not important. Organic clothing is a reflection of one's environmental friendly values and seeking conformance from others was not considered necessary. The research posits that past experience with other organic products and brands is likely to influence future purchase behaviour. It may imply the relevance of green lifestyle where youth wish to endorse green values. Drawing from Niinimaki's [40] study on eco-clothing, it is argued that consumers' ethical values and attitudes influence their green apparel buying decisions. Relating with environmental identity theory, purchasing green apparels enabled youth to differentiate themselves. It helped in projecting a pro-environmental and eco-friendly self-identity. Therefore, consumers' desire to conform to social norms was not relevant. It can be interpreted that youth symbolize green apparel as products which bestow pro-environmental identity. For some youth it may be 'fashionable' to project an environmentally friendly identity. For youth not interested in green apparel, factors such as style, price, brand name, and fashion may be important, and green apparel may not fit in their evoked set of needs.

The findings of the research can help organic clothing manufacturers and retailers to position and market their clothing brands. Since, youth comprises of a large segment that purchases clothing brands and is conscious about latest fashions and styles, organic clothing manufacturers should design promotions to educate youth about advantages of organic clothing and its impact on environment. The organic clothing brands can be related to environmental friendly values and lifestyles [41,42]. Promotional campaigns should educate and inform people about impact of textile manufacturing and dyeing processes on environment. Social initiatives like environment awareness camps, exhibitions of organic clothing, and fabrics that could be recycled could help in communicating the benefits. Organic clothing brands could use national and international designers as opinion leaders to communicate benefits of organic clothing. Latest designs and styles should be introduced to appeal to young consumers. The premium value of organic clothing lines can be emphasized by designing garments that are latest in line with global fashions.

Branding of green apparel lines by apparel firms would help in changing consumers' perception about organic products. Quality, price, and style aspects can be better managed through brands. Promotion of organic clothing can be done in fashion shows and other national apparel events. This would create awareness about organic apparels. Celebrities can be used to promote organic clothing lines. The organic clothing brands should focus on strengthening the attributes most important for youth.

\section{Conclusion}

The focus of this study was to understand the role of various factors that influence organic clothing buying behaviour like past green buying, green attitudes, values, green self-identity and peer influence on green buying. It investigates the role of these factors on organic clothing purchase. Future research can be directed in understanding these factors in context of organic clothing purchase. Primary research can help in understanding consumers' ecological beliefs. Specific green apparel brands, their prices, styles and promotions can be taken to understand their influence on consumers' attitude towards green apparel (Appendix).

\section{Appendix}

\begin{tabular}{|c|c|c|}
\hline & Consumers' Susceptibility to Interpersonal Influence Scale (Bearden et al. [41]) & Results of Qualitative Study \\
\hline 1 & I rarely purchase the latest fashions products until I'm sure my friends approve of them. & Removed \\
\hline 2 & It is important that others like the products and brands that I buy. & Removed \\
\hline 3 & $\begin{array}{c}\text { When buying products, I generally purchase those brands that I think others will approve } \\
\text { of. }\end{array}$ & Retained \\
\hline 4 & $\begin{array}{c}\text { If other people can see me using a product, I often purchase the brand they expect me to } \\
\text { buy. }\end{array}$ & Retained \\
\hline
\end{tabular}




\begin{tabular}{|c|c|c|}
\hline 5 & I like to know what brands and products make good impression on others. & Retained \\
\hline 6 & $\begin{array}{l}\text { I achieve a sense of belonging by purchasing the same products and brands that others } \\
\text { purchase. }\end{array}$ & Retained \\
\hline 7 & If I want to be like someone, I often try to buy the same brands that others purchase. & Retained \\
\hline 8 & $\begin{array}{l}\text { I often identify with other people by purchasing the same products and brands they } \\
\text { purchase. }\end{array}$ & Retained \\
\hline 9 & $\begin{array}{c}\text { To make sure I buy the right product or brand, I often observe what others are buying and } \\
\text { using. }\end{array}$ & Retained \\
\hline 10 & If I have little experience with a product, I often ask my friends about the product. & Retained \\
\hline 11 & $\begin{array}{c}\text { I often consult other people to help choose the best alternative available from a product } \\
\text { class. }\end{array}$ & Retained \\
\hline \multirow[t]{2}{*}{12} & I frequently gather information from friends and family about a product before I buy. & Retained \\
\hline & Peer Influence in Green Context Scale (Lee [25]) & \\
\hline 13 & I have learnt a lot about environmental issues from my friends. & Retained \\
\hline 14 & My friends often discuss about the environmental issues/products with me. & Retained \\
\hline 15 & My friends, often, recommend environment friendly products to me. & Retained \\
\hline 16 & My friends often go shopping for green products with me. & Retained \\
\hline \multirow[t]{2}{*}{17} & My friends often share their experiences and knowledge about green products with me. & Retained \\
\hline & Green Gauge Past Buying Behaviour Scale (Pickett-Baker [30]) & \\
\hline 18 & I use biodegradable soaps or detergents. & Retained \\
\hline 19 & I avoid buying aerosol products. & Retained \\
\hline 20 & I read labels to see if contents are environmentally safe. & Retained \\
\hline 21 & I buy products made or packaged in recycled materials. & Retained \\
\hline 22 & I buy products in packages that can be refilled. & Retained \\
\hline 23 & I avoid buying products from companies which are not environmentally responsible. & Retained \\
\hline 24 & I recycle bottles, cans or glass. & Removed \\
\hline 25 & I recycle newspapers. & Retained \\
\hline 26 & I compost garden waste. & Retained \\
\hline 27 & I take my own bags to the market. & Retained \\
\hline 28 & I try to cut down on car use. & Retained \\
\hline 29 & I contribute money to environmental causes. & Retained \\
\hline 30 & I am a volunteer for an environmental group. & Retained \\
\hline \multirow[t]{2}{*}{31} & I write to politicians about environmental problems. & Retained \\
\hline & Green Apparel Knowledge Scale (Kim [42]; Phua [3]) & \\
\hline 32 & $\begin{array}{l}\text { Chemical pollutants are produced during manufacturing of synthetic or manufactured } \\
\text { fibres such as polyester. }\end{array}$ & Retained \\
\hline 33 & Chemical pollutants are not produced during processing of natural fibers such as cotton. & Retained \\
\hline 34 & $\begin{array}{l}\text { Regionally mandated standards for clean air and water have not yet been imposed on } \\
\text { textile companies. }\end{array}$ & Retained \\
\hline 35 & Air pollution can occur during some common dye processes of textiles. & Removed \\
\hline 36 & Dyeing and finishing processes use lot of water. & Retained \\
\hline 37 & Fibers such as wool cannot be commercially recycled. & Retained \\
\hline 38 & $\begin{array}{l}\text { Disposable diapers have substantially contributed to the quantity of textile products } \\
\text { discarded in landfills. }\end{array}$ & Retained \\
\hline 39 & Special finishes on fabrics may create problems for recycling. & Retained \\
\hline 40 & Phosphate-containing detergents can be a source of water pollution. & Retained \\
\hline 41 & Natural fibers are usually bio-degradable. & Retained \\
\hline 42 & $\begin{array}{c}\text { The use of larger quantities of natural fibers will significantly decrease energy } \\
\text { consumption. }\end{array}$ & Retained \\
\hline
\end{tabular}




\begin{tabular}{|c|c|c|}
\hline & Green Apparel Buying Behaviour Scale (Kim \& Damhorst [42]) & Retained \\
\hline 43 & I buy apparel made from recycled material. & Retained \\
\hline 44 & I buy second-hand apparel. & Retained \\
\hline 45 & $\begin{array}{c}\text { I purposely select fabrics that require cooler washing temperature, shorter drying time, or } \\
\text { less ironing. }\end{array}$ & Retained \\
\hline 46 & I avoid an apparel product because of environmental concerns. & Retained \\
\hline 47 & I select apparel that I can wear over a longer term compared to trendy apparel that goes \\
\hline 48 & I but of style quickly. & Retained \\
\hline 49 & I buy apparel with low impact or no dye processing. & Retained \\
\hline 50 & I buy apparel with environmentally friendly labeling or packaging techniques. & \\
\hline
\end{tabular}

\section{References}

1. Fraj E, Martinez E (2002) Ecological consumer behavior. Esic Editor.

2. Junaedi MFS (2007) The roles of consumer's knowledge and emotion in ecological issues: An empirical study on green consumer behaviour Gadjah Mada Int J Bus 9(1): 81-99.

3. Phau I, Ong D (2007) An investigation of the effects of environmental claims in promotional messages for clothing brands. Mark Intell Plan 25(7): 772-88.

4. Chan RYK (2001) Determinants of Chinese consumers' green purchase behaviour. Psychology Marketing 8(4): 389-413.

5. Fraj E, Martinez E (2006) Environmental values and lifestyles as determining factors of ecological consumer behaviour: an empirical analysis. J Consum Mark 23(3): 133-44.

6. Maheshwari A, Malhotra G (2011) Green marketing: A study on Indian youth. Int J Manag Strateg 2(3): 1-15.

7. Saxena RP, Khandelwal PK (2012) Greening of industries for sustainable growth. Int J Soc Econ 39(8): 551-86.

8. Thakur K, Gupta S (2012) Exploration of Green Shift: Shift from trendy marketing to environmental friendly green marketing. Int J Arts Commer 1(7): 122-33.

9. Singh P, Pandey K (2012) Green marketing: policies and practices for sustainable development. Integral Review 5(1): 22-30.

10. Sahni H (2012) Indian apparel market: current status and future outlook. Indian Textile Summit, India.

11. Menon B (2009) Luxury brands are back to wooing Indian customer. Business Line, India.

12. Khare A, Sadachar A (2017) Green apparel buying behaviour: A study on Indian youth. Int J Consum Stud 41(5): 558-569.

13. Malviya S (2012) Future group to pitch mother earth Chain against retailer Fab India. The Economic Times, India.

14. Ghosh D (2010) Demand for eco-friendly apparel grows [Internet]. The Economic Times, India.

15. The Hindu (2010) Two major Indian apparel brands go organic. The Hindu, India.

16. Mehta V (2012) Emerging issues in apparel trade. Apparel Export Promotion Council pp. 1-14

17. Roozen ITM, De Pelsmacker P (2000) Polish and belgian consumers' perception of environmentally friendly behaviour. J Consum Stud Home Econ 24(1): 9-21.

18. Bang HK, Ellinger AE, Hadjimarcou J, Traichal PA (2000) Consumer concern, knowledge, belief, and attitude toward renewable energy: An application of the reasoned action theory. Psychology \& Marketing 17(6): 449-468.

19. Chan RYK, Lau LBY (2002) Explaining green purchasing behaviour. J Int Consum Mark 14(2-3): 9-40.

20. Hartmann P, Apaolaza Ibáñez V, Forcada SFJ (2005) Green branding effects on attitude: functional versus emotional positioning strategies. Mark Intell Plan 23(1): 9-29.

21. D'Souza C, Taghian M, Lamb P (2006) An empirical study on the influence of environmental labels on consumers. Corp Commun an Int J 11(2): 162-173

22. Harland P, Staats H, Wilke HAM (2007) Situational and personality factors as direct or personal norm mediated predictors of pro-environmental behaviour: Questions derived from norm-activation theory. Basic and Applied Social Psychology 29(4): 323-334.

23. Mostafa MM (2007) A hierarchical analysis of the green consciousness of the Egyptian consumer. Psychology \& Marketing 24(5): 445-473.

24. Lee K (2008) Opportunities for green marketing: young consumers. Mark Intell Plan 26(6): 573-586.

25. Lee K (2009) Gender differences in Hong Kong adolescent consumers green purchasing behaviour. J Consum Mark 26(2): 87-96.

26. Park J, Ko E, Kim S (2010) Consumer behaviour in green marketing for luxury brand: A cross-cultural study of US, Japan and Korea. Journal of Global Academy of Marketing Sciences 20(4): 319-333.

27. Kalafatis SP, Pollard M, East R, Tsogas MH (1999) Green marketing and Ajzen's theory of planned behaviour: a cross-market examination. J Consum Mark 16(5): 441-460

28. Kim H, Chung J (2011) Consumer purchase intention for organic personal care products. J Consum Mark 28(1): 40-47.

29. Cheah I, Phau I (2011) Attitudes towards environmentally friendly products. Mark Intell Plan 29(5): 452-472.

30. Pickett-Baker J, Ozaki R (2008) Pro-environmental products: marketing influence on consumer purchase decision. J Consum Mark 25(5): 281-293.

31. Chan K (2000) Market segmentation of green consumers in Hong Kong. Journal of International Consumer Marketing 12(2): 7-24.

32. Young W, Hwang K, McDonald S, Oates CJ (2010) Sustainable consumption: green consumer behaviour when purchasing products. Sustainable Development 18(1): 20-31.

33. Borin N, Cerf DC, Krishnan R (2011) Consumer effects of environmental impact in product labeling. J Consum Mark 28(1): 76-86.

34. Gam HJ (2011) Are fashion-conscious consumers more likely to adopt eco-friendly clothing? J Fash Mark Manag an Int J 15(2): 178-193. 
35. Gam HJ, Cao H, Farr C, Kang M (2010) Quest for the eco-apparel market: a study of mothers' willingness to purchase organic cotton clothing for their children. International Journal of Consumer Studies 34(6): 648-656.

36. Lin SH (2010) A case study in Hawaii: who will pay more for organic cotton? International Journal of Consumer Studies 34(4): 481-489.

37. Ellis JL, McCracken VA, Skuza N (2012) Insights into willingness to pay for organic cotton apparel. J Fash Mark Manag an Int J 16(3): 290-305.

38. Khare A, Varshneya G (2017) Antecedents to organic cotton clothing purchase behaviour: study on Indian youth. J Fash Mark Manag an Int J 21(1): 51-69.
39. Jansson J, Marell A, Nordlund A (2010) Green consumer behaviour: determinants of curtailment and eco-innovation adoption. Journal of Consumer Marketing 27(4): 358-370.

40. Niinimäki K (2010) Eco-clothing, consumer identity and ideology. Sustainable Development 18(3): 150-162.

41. Bearden W, Netemeyer R, Teel J (1989) Measurement of consumer susceptibility to interpersonal influence. Journal of Consumer Research 15(4): 473-481.

42. Kim HS, Damhorst ML (1998) Environmental concern and apparel consumption. Clothing and Textile Research Journal 16(3): 126-133.

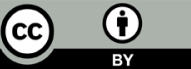

Creative Commons Attribution 4.0 International License

For possible submissions Click Here

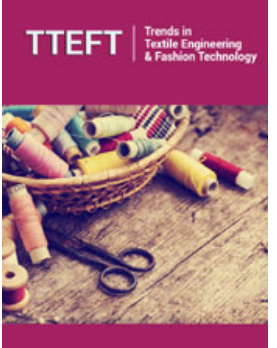

Trends in Textile Engineering \& Fashion Technology

\section{Benefits of Publishing with us}

- High-level peer review and editorial services

- Freely accessible online immediately upon publication

- Authors retain the copyright to their work

- Licensing it under a Creative Commons license

- Visibility through different online platforms 